Academic
$\begin{aligned} & \text { Journal of } \\ & \text { Islamic Studies }\end{aligned}$ $\begin{array}{r}\text { Institut Agama Islam Negeri (IAIN) Curup, Indonesia } \\ \text { ISSN 2580-3174, (p); 2580-3190 (e) } \\ \text { volume 6, number 2, 2021 | page: 245-262 } \\ \text { DOI: http://doi.org/10.29240/ajis.v6i2.3501 }\end{array}$

\title{
A Habituation Method in Education Character: an Ibn Miskawaih Thought
}

\author{
Hadi Candra, Pristian Hadi Putra, Yelni Erniyati \\ Insitut Agama Islam Negeri (IAIN) Kerinci, Indoneisa \\ Correspondence: fristianhp87@gmail.com
}

\begin{abstract}
The learning experience of education in Indonesia, as described in the Character Education Master Design document, is built through a habituation approach. Meanwhile, Ibn Miskawaih states that character building is created through habit and practice. The synchronization of both is needed to optimize the implementation of character education in Indonesia today. Habituation in character education is a form of practice that is carried out continuously from the cognitive and practical faculties, which are actualized in behavioral attitudes, by directing them to perfection gradually, based on the thought, until they get used to these behavioral attitudes, then this condition continues until the end of time. In a relatively long time, it becomes a character.
\end{abstract}

Keywords: Thought, Habituation Method, Character

\section{Introduction}

Looking at the reality that is happening at this time, along with the globalization, there has been a shift in values and a decline in morals. On one side, there has been a very rapid progress in technology and science in order to fulfill needs and to help facilitating human beings. On the other side, there is the decline of moral values in life, such as the various media which report the cases of rape, obscenity, theft and so on. This shows that the more modern humans are, the greater the challenges they experience. In this regard, in the face of globalization, it is best not to be a priori and rejects it. However, it is better to be selective, trying to filter and instill good characters in all elements of the nation, preparing them to face the challenges of globalization.

Related to such conditions, it is necessary to have the right solution for the resolution of the nation's problems, namely the existence of noble character development for all elements of the nation. It was conveyed by the sixth President of the Republic of Indonesia, Susilo Bambang Yudoyono: 
"Character building is very important. We want to build Indonesian people who are moral, virtuous, and noble. Our nation also wants to have a superior and noble civilization. We can achieve such a civilization if our society is also a good society. In addition, we can realize this ideal society when Indonesian people are human beings with good manners, good morals, and good ethics, as well as humans who speak and behave well" .1

The right way to do that is through education. Through education, it is hoped that there will be a transformation that can foster positive character. The education in this case is precisely character education. The approach that can be used in instilling the character is by using a habituation approach. The habituation approach is the most effective alternative in implementing character education because when the characters are accustomed to life and carried out continuously, the character will be attached and become a personal identity.

The habituation approach is further explained in the micro context of character education. In the micro context, the character development takes place in the context of a holistic education unit (the whole school reform). Character development programs on micro settings can be described as follows:

1Kemendiknas, Desain Induk Pendidikan Karakter, (Jakarta: Kemendiknas, 2010), 3. 


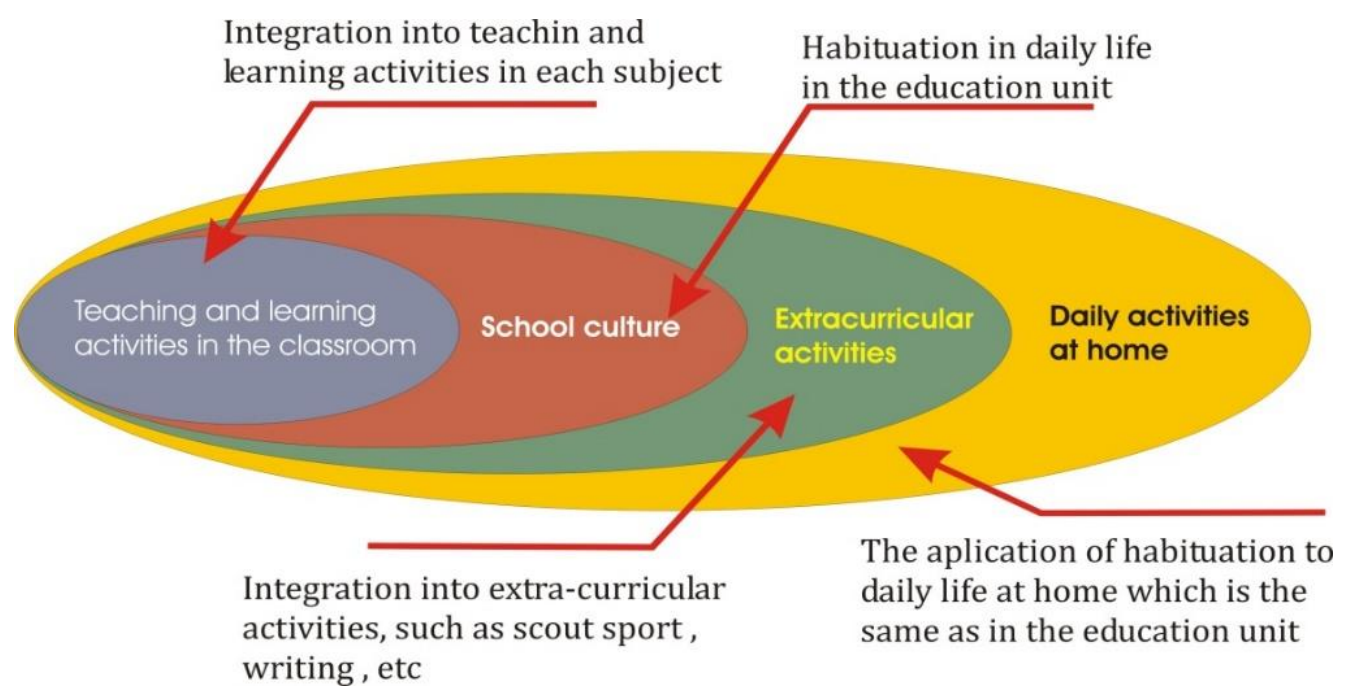

figure 1. character education micro context

On a micro level, the development of character values in each pillar realizes habituation. In the micro concept, it is stated, "it is necessary to develop a process of habituation and strengthening in the context of character development". This means that the development of character values in Indonesia applies the approach/method of habituation. ${ }^{2}$

The role of the habituation method greatly affects the achievement of the goals of character education. Because of that, every educator should understand the habituation method. The educators need to realize that in the personal development of the students. A habituation method is needed by adjusting the habits according to the mental development of students.

The valid/the authentic sources will be obtained, including by the writings of scholarly personages. Abu Bakr ar-Razi, Ibn Miskawaih, al Ghazali, and others are Muslim intellectual figures who discuss morals in a philosophical ways. From these figures, Ibn Miskawaih is a figure who is considered meritorious in the development of Islamic moral discourse and emphasizes habituation in character education. Ibn Miskawaih is the most famous and greatest Persian theistic thinker, moralist and historian of his time. ${ }^{3}$ Ibn Miskawaih is the first Islamic thinker in the field of

Kemendiknas, Desain, 27.

${ }^{3}$ M. Syarif, Para Filosof Muslim,(Cet.11; Bandung: Mizan, 1998), 83-84. 
morality, ${ }^{4}$ so that he is considered as the Father of Islamic Ethics. "A Muslim philosopher who firstly wrote about ethical theory and wrote about ethics book, Ibn Miskawaih is also known as a great historian whose fame exceeds his predecessor, al-Tabari (310 H/923 AD)".5

In addition, the basic concept of moral education from the thoughts of Islamic intellectuals such as Ibn Miskawaih, has brought up the various concepts and further thoughts and is growing, both theoretically and practically.

This research is a qualitative research, with the type of library research, focusing on the type of study of the character's thinking. In this study, the researchers examine and analyze the various supporting literatures in order to get Ibn Miskawaih's thoughts on the habituation method. Researchers conduct studies on data contained in books, journals, archives or related documents and so on. By the development of information technology, data are also obtained through the electronic

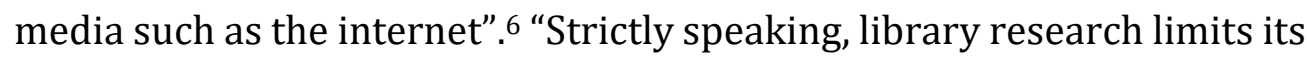
activities only to library collection materials without the need for field research". ${ }^{7}$

Data collection techniques in this study were analyzing the text and discourse, and studying the documents ${ }^{8}$. The data which had been collected were then analyzed by means of data reduction, data display and drawing conclusion.

Finding and discussion

The Concept of Ibn Miskawaih's Thought on the Method of Habituation

\section{The definition of Habituation}

\footnotetext{
${ }^{4}$ Suwito, Filsafat Pendidikan Akhlak Ibnu Miskawaih, (Yogyakarta: Belukar, 2004), 201.

5Suwito, Filsafat, 68.

${ }^{6}$ Sutrisno Hadi, Metodologi Research, vol. II, (Yogyakarta: Andi Ofset,1990), 9.

${ }^{7}$ Mestika Zed, Metode Penelitian Kepustakaan, (Jakarta: Yayasan Obor Indonesia, 2008), 1-2.

${ }^{8}$ Amir Hamzah, Metode Penelitian Kepustakaan: Library Research, (Malang: Literasi Nusantara Abadi, 2019), 25
} 
Ibn Miskawaih emphasized the possibility of a change in morals mainly through education, that is, from the habit and the practice. Habits can be expressed as the result of practice. Therefore, there is a close relationship between habit and practice. This shows that habituation can be done with serious and continuous practice, so that habits are formed. Ibn Miskawaih stated:

"Character (khuluq) is a condition of the soul. This condition causes the soul to act without thought or deep consideration. This situation is of two types. The first are natural and opposite from the character. The second, created through habit and practice. At the first, these conditions occur due to the consideration and the thought, but then, through continuous practice, it becomes character". 9

Ibn Miskawaih's opinion seems to be the same as what was conveyed by Thorndike in the law of exercise that, "if the response to the stimulus is repeated, it will strengthen the relationship between the response and the stimulus. On the contrary, if the response is not used, the relationship with the stimulus is getting weaker".10

Ibn Miskawaih s' statement is also in accordance with what is in psychology. The process of habituation is called "conditioning". According to the conditioning theory, "learning is also defined as a process of change that occurs because of the conditions which then cause a reaction (response). To make someone learn, we must provide certain conditions, the most important thing according to this theory is continuous practice. In this theory, the priority is learning that occurs automatically.".11 "“This process will incarnate habits and abilities, which will eventually become personal traits (personal habits) that are tempered in daily behavior". ${ }^{12}$ Therefore, to obtain good habituation results, it is necessary to practice repeatedly in the right order and regularly.

\footnotetext{
9'Ibn Miskawaih. Tahdzib al-Akhlaq wa Tathir al-A'raq, translated by Helmi Hidayat, Menuju Kesempurnaan Akhlak, (Cet.4, Bandung: Penerbit Mizan, 1998), 56.

${ }^{10}$ Evelin Siregar and Hartini Nara. Teori Belajar dan Pembelajaran, (Bogor: Ghalia Indonesia, 2011), 29.

11Sumadi Suryabrata. Psikologi Pendidikan, (Jakarta: Rajawali press, 1984), h. 284.

12Hanna Djumhana. Integrasi Psikologi dengan Islam Menuju Psikologi Islami, (yogyakarta: Yayasan Insan Kamil dan Pustaka Pelajar, 2001), 6.
} 
Ibn Miskawayh also said, "A person's virtue is measured by the extent to which he seeks and desires the virtue. This virtue will increase more and more, when he pays more attention to his soul and tries hard to get rid of everything that hinders him from achieving virtue". ${ }^{13}$ For this reason, even though at the first it is started as forced, but continued to be trained and accustomed, it is hoped that it will become a habituation towards goodness and glory, as Ibn Miskawaih states a s follow:

"Although initially carried out by forcing, considered, and thought out beforehand, however, with a genuine will to practice continuously and restraint (al-'adat wa al-jihad), it will be obtained the virtue and courtesy that are actually in accordance with the virtues soul".14

Habituation of good character is closely related to cognitive processes (faculty of thinking), in which these activities are part of learning that is carried out and trained continuously. Ibn Miskawaih's opinion is explained further as Zakiah Darajat states, "should be in the learning process, the earlier the child's age, the more habituation is carried out on the child, and by the increasing age of the child should also increase the explanation and understanding given in accordance with the development of the child intelligence". ${ }^{15}$

In order to achieve the virtue, it takes practice as a habituation to the soul. Thus, the thinking soul is always trained to get used to interpret and understand the meaning and the purpose of learning and doing. For this reason, according to Ibn Miskawaih, "Humans always experience the increasing of understanding, when they continue to practice, and then produce various science and knowledge".16

Based on the information above, it can be understood that what is meant by the habituation in character education is a practice that is carried out consistently, regularly and continuously for the soul that is actualized from behavioral attitudes. Then, it is associated with the soul

\footnotetext{
13Ibn Miskawaih. Tadhzib, 39.

${ }^{14}$ Suwito. Filsafat, 136.

15Zakiah Darajat, Membina Nilai-nilai Moral di Indonesia, Jakarta: Bulan Bintang, 1976), 74

16Ibn Miskawaih. Tahdzib, 4.
} 
until the animated automatic attitudes are formed in the soul, by involving cognitive function (based on correct understanding), so that the noble character is formed.

\section{Habituation Goals}

Ibn Miskawaih said, "Character (khuluq) is a condition of the soul that causes the soul to act without thought or deep consideration".17 Based on the understanding conveyed, the word "without thinking or considering" indicates that spontaneity in action becomes an emphasis of Ibn Miskawaih in his moral education. Therefore, the purpose of habituation of Ibn Miskawaih's view is "the realization of an inner attitude that is able to spontaneously encourage all actions that are of good value, so that they can achieve perfection and obtain true and perfect happiness (al-sa'adat)".18 Because "as a result of habituation, it will produce a habit in certain behaviors that are automatic, without being planned in advance, and carried out just like that without thinking about it".19

It can be seen that Ibn Miskawaih underlies his moral education on the form of happiness that will be obtained by humans in this world and in the hereafter. That is why he thinks people who have good character are the happy people. In this case, if one has understood and can master the cognitive and practical faculties, then train and familiarize these faculties with regular actions, then one will not deviate from His (Allah SWT) original wisdom order so that perfection is realized and a sense of happiness is created.

Based on this, it means that the purpose of habituation offered by Ibn Miskawaih is aimed at the encouraging humans to behave well in order to achieve happiness (as-sa'adah). According to him, people with noble character are the happy people. "The happiness of the soul is the most perfect happiness and is able to lead humans to have the highest degree (angel)". 20

17Ibn Miskawaih. Tadhzib, 56.

${ }^{18}$ Abuddin Nata. Pemikiran Pendidikan Islam dan Barat, Cet. 2, Jakarta: Raja Grafindo Persada, 2013), 11-12

${ }^{19}$ M Furqon Hidayatullah. Pendidikan, 41.

${ }^{20}$ Hasyimiyah NasutionFilsafat Islam, Jakarta: Gaya Media Pratama, 2013), 70 
The further or final goal that Ibn Miskawaih wanted spontaneously in habituation was as intended in the purpose of moral education, namely, "the creation of human actions as divine actions (af'al ilahiyyat)". ${ }^{21}$

\section{Habituation background}

Ibn Miskawaih does not directly mention the basis of habituation either orally or from his writings. It is just that in the discussion of Tahdzib, religious law and matters of the soul are the main discussions associated by Ibn Miskawaih with the habituation in moral/character education.

a. Religious Law (syari'ah)

The main purpose of religious teachings is to provide and teach the noble character. This is as same as with the apostolic mission carried out by the prophet Muhammad SAW which is to perfect human morals.

Religion and education character have a very close relationship in perfecting and improving the human morality. Ibn Miskawaih views that religion is something that is very urgent in getting used to and straightening habits to do the goodness. Ibn Miskawaih says that:

"Religious law is a factor that straightens the character of teenagers, which accustoms them to do the good deeds, as well as which prepares them to receive the wisdom, seek the virtue, and achieve the happiness through accurate thinking and reasoning". 22

Ibn Miskawaih's explanation emphasizes the importance of religious law in getting used to be good character. It is because when the mind, the knowledge, and Allah's laws regarding human functions as caliphs on earth are aligned, humans will try to build good habits in themselves.

b. the Soul Concept

21Suwito. Filsafat, 118.

${ }^{22}$ Ibn Miskawaih.Tahdzib, terj Helmi Hidayat, 59-60. 
The thought of Ibn Miskawaih's moral/character education was built on his view of the soul. Therefore, the concept of habituation according to Ibn Miskawaih begins with exploring the human soul.

Ibn Miskawaih mentions about the three faculties of the human soul as conveyed, namely,

"There are the faculties of human soul; the soul of thinking (al-quwwahal-natiqah), the soul of lust (al-Bahimmiyah/assyahwiyah), the soul of courage (as-sabu'iyyah/alghadabiyyah). The three faculties of the soul can be strong or weak, depending on the temperament, the habit, or the discipline. The overdevelopment of one of the three faculties undermines the others, and that one of the three can negate the action of the other. This condition of the soul will cause an element of deterioration". ${ }^{23}$

Ibn Miskawaih said that the goodness would be obtained if the relationship between the three faculties of the soul is in harmony according to their nature. Therefore, the soul needs to be trained to get used to always being in stability and harmony. For this reason, according to Ibn Miskawaih, moral/character education and knowledge of the soul are closely related. Therefore, the thought of Ibn Miskawaih's moral/character education regarding to the habituation was built on his view of the soul.

\section{The principles of habituation}

a. Sustainable and gradual according to soul formation sequence

The character formed is influenced by the faculties of the soul that humans have. These faculties naturally arise or develop gradually in humans. Therefore, habituation should be carried out in stages that are adjusted to the order in which the faculties arise in humans. This method appears from the observations about faculties/powers

b. Integrated in the Various Fields of Science 
The application of habituation in the context of character development according to Ibn Miskawaih, can be interpreted that in principle, it is integrated in the various fields of science.

According to Ibn Miskawaih, by getting used to or always studying the science of logic, knowledge will be obtained based on its characteristics. Then, with this knowledge, it will be obtained Divine knowledge that can cause us to draw closer to the Divine. If you have reached this stage, then you are ready to receive the grace of Allah SWT. His mercy will come, and will be free from the turmoil of animal lust because of the closeness to Allah SWT. In this case, it will be seen the levels of existence that have been passed gradually, and it will be known that the existence of each level requires the previous level.

\section{c. Starting from the Early Age}

Habituation in character education is carried out as early as possible. That is because the souls of children are not influenced by negative things. It is better if the souls that are still empty of negative things are filled with the elements relating to positive things, namely the matters related to religious law. This is as stated by Ibn Miskawaih below:

"Religious law must be trained and educated from the childhood to get used to do it. Maybe we have noticed a small child who bows his head and looks shy and does not even dare to look at us, this can be categorized as early evidence that the child is able to distinguish between the good and the bad. In addition, such actions show that this kind of soul is ready to receive education and is suitable to be nurtured and cared for". ${ }^{24}$

In order to make the good habit be imprinted into the child's soul as early as possible, it must be accustomed continuously until it becomes a part of him until later adulthood. Thus, the habituation method is a practical method in shaping the character of early childhood in improving 
habits in carrying out an activity at school. 25 "Habituation done from an early age will bring those hobbies and habits into a kind of custom, so that they become an inseparable part of the personality". ${ }^{26}$

d. Habituation Supporting Factors

Building the character by using the habituation method needs to be considered for things that can support its implementation so that the desired results are obtained. Some things that need to be considered to be implemented according to Ibn Miskawaih include the followings:

\section{1) Emptying Yourself of Despicable Traits}

Ibn Miskawaih says that everyone has his or her own happiness. Therefore, everyone must empty himself of despicable qualities and get used to inculcate the commendable qualities. Therefore, Allah SWT will put the light in the heart to recognize the nature of lust. Ibn Miskawaih argues that,

"The most important foundation is the necessity to clean oneself of the despicable qualities firstly, before filling it with the main qualities. This is very important, because in life experiences we always find that we, for example, will not be able to build a good, clean and healthy building on a pile of garbage, mud and dirty". 27

\section{2) Focus on the Purpose of Human Creation}

Ibn Miskawaih says that goodness is something that can be achieved by humans. This was also conveyed by Anas Salahudin, namely, "education should aim to serve and actualize the role of the human caliphate on earth". ${ }^{28}$

In this case, in habituation, the students should know and understand the nature of the purpose of life or the creation of humans in

\footnotetext{
${ }^{25}$ Muhamad Fadilah Dan Lilif Mualifatu Qorida, Pendidikan Karakter Anak Usia Dini, ( Yogyakarta: Arruz Media, 2013), 173.

26Amirulloh Syarbini, Model Pendidikan Karakter dalam Keluarga; Revitalisasi Peran Keluarga dalam Membentuk Karakter Anak Menurut Perspektif Islam, (Jakarta: Gramedia, 2014), 87.

27Ibn Miskawaih, Tahdzib, terj Helmi Yahya, 14.

${ }^{28}$ Anas Salahudin dan Irwanto Alkrienciehie, Pendidikan Karakter, Pendidikan Berbasis Agama dan Budaya Bangsa, (Bandung: Pustaka Setia, 2013), 51.
} 
this world. Therefore, the habituation carried out is as self-serving to the creator, Kholik, and as a manifestation of the role of humans as caliphs on this earth who will be asked the responsible both in this world and in the hereafter. Thus, the habituation carried out becomes meaningful and has a clear direction.

\section{3) Seeking the goodness}

According to Ibn Miskawaih, the virtue of a person is measured by the extent to which he strives and desires the virtue. We must strive for the good, which is our perfection, for which goodness we were created.

Ibn Miskawaih explains that no matter how difficult it is; if there is revolutionary courage within us, new habits will emerge that make us more individuals that are independent because we are able to determine our own destiny. Generally, it must be accompanied by an element of coercion and compulsion, especially if it is accompanied by an element of laziness or reluctance to implement it. We have to be forced often to do certain activities at first, before we enjoy them.

\section{4) Avoiding the bad things}

In order to good habits that are cultivated can be successful, according to Ibn Miskawayh, we must stay away from the bad things that prevent us from getting the good or reduce the good we have. Do not approach every bad deed that is cursed by Allah SWT. Avoid associating with the people whose words say things that are not good, especially if they are playmates.

Ibn Miskawayh said that, "It should not be ignored or allowed to associate with the people who have bad morals who will damage their souls. Prevent the child, lest he be among people who like to drink liquor. Let him be among many pious and noble people." 29 This is so that he does not hear vile words and does not see their lowly deeds.

5) Knowing Your Shortcomings and Needs

According to Ibn Miskawaih, knowing one's own shortcomings and needs are the factor that must be done by humans as the part of getting 
used to doing well. Knowing one's own shortcomings aims to improve the shortcomings that exist in oneself, both physical and related to the soul. That is by reducing gradually or removing all bad things and filling them with good or positive things.

Knowing the shortcomings and needs of oneself is a necessary factor in habituation. It takes the faculty of thinking to know all things that are self-deficient and all needs that must be met.

\section{6) Interaction and Cooperation (as a social process)}

Ibn Miskawaih argues that humans cannot achieve the perfection by living alone. In order to apply the habituation of good habits, the human must socialized and supported by others and society, so that his life is good and he follows the right path. Humans need a place in which there is a certain community so that human happiness can be achieved. Humans certainly need other humans besides themselves. That way, he must be friends with other humans that must love him sincerely.

From the information above, it can be explained that the character building through habituation will be effective if there is support from the environment. There are needs to be a synergy of good habits between all components of society.

\section{7) Fortitude/Integrity}

Habituation in character education must be accompanied by personal fortitude and toughness, so that the individuals can overcome various obstacles faced when carrying out all good habits. "The key of success does not lie in anyone, not in other people, or existing facilities, but in self-centeredness. In addition, it can only be achieved when we are able to learn to be strong individuals not only in one side of life, but also in all areas of life." 30 It is not easy to do, but it is possible to do it

8) The Existence of Advisor/Coach

According to Ibn Miskawaih, in character education with regard to the habituation, in order to be carried out properly, it is very necessary to

${ }^{30}$ E.Widijo Hari Murdoko, Menjadi Pribadi Revolusioner, (Yogyakarta: Wanajati Chakra Renjana, 2012), 123. 
have a mentor/coach. Without the help of a guide or educator, success will be difficult to obtain. Only the supervisor will be able to direct about how the habituation should be carried out, what things are needed, and what shortcomings or weaknesses that must be corrected. Only the trainer/supervisor will be able to control the habituation activities so that they are appropriate.

e. Habituation in Character Education

The purpose of character education through the habituation according to Ibn Miskawaih is the perfection of character accustomed to the human life such as:

\section{1) Habituation to the Human Soul}

Ibn Miskawaih explains that people will be noble if their thinking soul is trained and accustomed to being able to lead and direct two other souls, namely the lustful soul/lust/animal (al-Bahimmiyah/assyahwiyyah) and the brave/angry soul (as-sabu'iyyat/al-Ghadabiyyah). The two souls should be accustomed to follow orders. Therefore, if the thinking soul follows the faculty of lust and the faculty of brave, it becomes a slave to both of them. It will be the destruction of a person due to being a slave to his desires due to always following his desires.

2) Habituation of Individuals in Achieving the Perfection

Based on the harmony condition of the soul, such soul condition is actualized through physical intermediaries. According to Ibn Miskawaih, "because when it is still in the soul and not yet actual, then it is an object. But if it is actualized and becomes perfect, then it is perfection." Actualization in the form of activities that are in accordance with the condition of the primacy of the soul is carried out consistently and continuously by involving the soul to animate within and programmed automatically as part of the self.

\section{3) Habituation in Adolescents and Children}

Ibn Miskawaih views that if people grow up with unscrupulous upbringing, they can no longer be expected to succeed, and there is no need to try to straighten them out. His thinking soul has become a slave to his beast soul and his angry soul. Because it has obeyed his lust, it is 
very difficult to educate a person who has grown up accustomed to this way, unless he recognizes the vileness of his behavior, blames it, and intends to break away from it and repent.

He should regard them as misery, not happiness, and loss, not fortune, and he should try to distance himself from so-called pleasures by indulging in his passions, but this is very difficult. However, it is better than doing falsehood for life. People like this can be expected to leave low morals to noble character through good habits, gradually, by repenting, staying away from evil and not being among people who do bad things, associating with good and wise people, pious and noble people. This shows that in habituation, Ibn Miskawaih emphasizes the element of exemplary. Ibn Miskawaih asks parents/adults to be aware of having noble character. Because they realize it or do not, they will be the role models by the children and adolescents around them.

\section{4) Habituation by Community Leaders}

According to Ibn Miskawaih, community leaders must be involved in character education, which can form good habits in life, towards the community. Community leaders should be able to train and familiarize the community with behavior that is in accordance with the values. It is the community leaders who will be able to encourage and pioneer every activity in society in creating conditions for people who are accustomed to good habits as a whole in social life.

From the description of the concept of habituation in character education according to Ibn Miskawaih's thought, it can be interpreted that someone who already has certain habits will be able to carry it out easily and happily. Even everything that has become a habit at a young age is difficult to change and persists into old age. Therefore, the good habits should always be accustomed to become an inherent character and be implemented in life.

\section{Conclusion}

Habituation in character education is a form of practice that is carried out continuously from the cognitive faculties and practical faculties, which are actualized in behavioral attitudes, by directing them 
to perfection gradually, based on thoughts, until they are accustomed to these behavioral attitudes, and then this condition continues until the end of time. In a relatively long time, it becomes a character. The purpose of habituation is the realization of a state of the soul that is able to spontaneously encourage all actions of good value so that they can achieve perfection and obtain true and perfect happiness (al-sa'adat). Therefore, humans are perfect in directing the human behavior to be good, aims to print good human behavior, to form a commendable attitude of behavior, and perfect in accordance with its substance as a human being.

This research focuses on the thoughts of ibn miskawaih regarding the character education by using a habituation approach, and it is hoped that the next author and researchers will explore and continue this research on the approaches and thoughts of other figures, and hopefully this research will be useful.

\section{Bibliography}

Darajat,Zakiah Membina Nilai-nilai Moral di Indonesia, Jakarta: Bulan Bintang, 1976

Djumhana, Hanna,Integrasi Psikologi dengan Islam Menuju Psikologi Islami, yogyakarta: Yayasan Insan Kamil dan Pustaka Pelajar, 2001

E.Widijo Hari Murdoko, Menjadi Pribadi Revolusioner, Yogyakarta: Wanajati Chakra Renjana, 2012

Evelin Siregar dan Hartini Nara. Teori Belajar dan Pembelajaran, (Bogor: Ghalia Indonesia, 2011

Hadi,Sutrisno,Metodologi Research , Jilid II, Yogyakarta: Andi Ofset,1990

Hamsah, Amir. Metode Penelitian Kepustakaan: Library Research, Malang: Literasi Nusantara Abadi, 2019.

Kemendiknas, Desain Induk Pendidikan Karakter, Jakarta: Kemendiknas, 2010

M. Syarif, Para Filosof Muslim,Cet.11; Bandung: Mizan, 1998), hlm. 83-84. 
Miskawaih, Ibn. Tahdzib al-Akhlaq wa Tathir al-A'raq, translated by Helmi Hidayat, Menuju Kesempurnaan Akhlak,Cet.4, Bandung: Penerbit Mizan, 1998

Muhamad Fadilah Dan Lilif Mualifatu Qorida, Pendidikan Karakter Anak Usia Dini, Yogyakarta: Arruz Media, 2013

Nasution, Hasyimiyah,Filsafat Islam, Jakarta: Gaya Media Pratama, 2013

Salahudin, Anas dan Irwanto Alkrienciehie, Pendidikan Karakter, Pendidikan Berbasis Agama dan Budaya Bangsa, Bandung: Pustaka Setia, 2013.

Suryabrata, Sumadi,Psikologi Pendidikan, Jakarta: Rajawali press, 1984

Suwito, Filsafat Pendidikan Akhlak Ibnu Miskawaih, Yogyakarta: Belukar, 2004

Syarbini, Amirulloh, Model Pendidikan Karakter dalam Keluarga; Revitalisasi Peran Keluarga dalam Membentuk Karakter Anak Menurut Perspektif Islam, Jakarta: Gramedia, 2014

Zed, Mestika Metode Penelitian Kepustakaan, Jakarta: Yayasan Obor Indonesia, 2008 
262 | AJIS : Academic Journal of Islamic Studies, vol. 6, no. 2, 2021

Empty page 